\title{
BIOREDUCTION AND CHARACTERIZATION OF SILVER NANOPARTICLES FROM OIL PALM EMPTY FRUIT BUNCH
}

\author{
Siti Suhartati ${ }^{1}$, Iwan Syahjoko Saputra ${ }^{2}$, Dwinna Rahmi ${ }^{3}$, Yoki Yulizar ${ }^{4}$, Sudirman $^{5}$ \\ ${ }^{1}$ Academy of Analytical Chemistry Caraka Nusantara \\ Jl.Tugu Raya Komplek Timah, Depok, 16951 \\ ${ }^{2}$ Study Programme of Cosmetic Technology, Department of Science Technology, Sumatera \\ Institute of Technology \\ Jl. Terusan Ryacudu, Way Hui, Jati Agung, South Lampung, 35365 \\ ${ }^{3}$ Balai Besar Kimia dan Kemasan, Kementerian Perindustrian RI \\ Jl. Balai Kimia I Pekayon, Pasar Rebo, Jakarta Timur, 13710 \\ ${ }^{4}$ Department of Chemistry, FMIPA-UI \\ Kampus Baru Universitas Indonesia, Depok, 16424 \\ ${ }^{5}$ Center for Science and Technology of Advanced Materials-BATAN \\ Puspitek Area, Serpong, South Tangerang, 15314 \\ E-mail: iwan.saputra@km.itera.ac.id
}

\begin{abstract}
BIOREDUCTION AND CHARACTERIZATION OF SILVER NANOPARTICLES FROM OIL PALM EMPTY FRUIT BUNCH (OPEFB). The synthesis of silver nanoparticles was successfully carried out by extracting oil palm empty fruit bunch. The precursor used was silver nitrate $\left(\mathrm{AgNO}_{3}\right)$ with a concentration of $9 \times 10^{-4} \mathrm{M}$ and $5 \mathrm{wt} \%$ of the oil palm empty fruit bunch extract. OPEFB acted as a capping agent in the synthesis of silver nanoparticles. The bioreduction method $\mathrm{Ag}^{+}$to $\mathrm{Ag}^{0}$ produced a silver nanoparticle colloid in brown color. The results of the UV-Vis spectrophotometer showed the silver nanoparticles colloids spectrum at a wavelength of $420 \mathrm{~nm}$ with an absorbance value of 0.5 . FTIR shows the reduction and shift of absorption peak in the hydroxyl functional group (-OH) at wavenumbers of $3323 \mathrm{~cm}-1$ and the presence of absorption peaks at $560 \mathrm{~cm}^{-1}$. While, XRD pattern showed the specific crystallinity peaks of silver nanoparticles at $2 \theta$ : $33.24^{\circ} ; 39.98^{\circ} ; 61.23^{\circ}$; dan $79.13^{\circ}$ respectively with the face-centered cubic crystal structure (FCC) and crystallite size of $15 \mathrm{~nm}$. PSA analysis showed two specific peaks with an average size distribution silver nanoparticles of $43.5 \mathrm{~nm}$ and a PDI value of 0.4 . Analysis of TEM shows the average particle size of $20 \mathrm{~nm}$ with a spherical particle shape.
\end{abstract}

Keywords: Bioreduction, Silver Nanoparticles, Oil Palm Empty Fruit Bunch

\begin{abstract}
ABSTRAK
BIOREDUKSI DAN KARAKTERISASI NANOPARTIKEL PERAK MENGGUNAKAN EKSTRAK TANDAN KOSONG KELAPA SAWIT. Sintesis nanopartikel perak berhasil dilakukan dengan memanfaatkan ekstrak tandan kosong kelapa sawit (TKKS). Prekursor yang digunakan yaitu perak nitrat $\left(\mathrm{AgNO}_{3}\right)$ dengan konsentrasi $9 \times 10^{-4} \mathrm{M}$ dan 5\% sampel ekstrak TKKS. Tujuan penggunaan ekstrak tandan kosong kelapa sawit adalah sebagai media sekaligus capping agent dalam sintesis nanopartikel perak. Metode bioreduksi $\mathrm{Ag}^{+}$menjadi $\mathrm{Ag}^{0}$ menghasilkan warna koloid nanopartikel perak berwarna coklat. Hasil spektrofotometer UV-Vis menunjukkan spektrum pada panjang gelombang $420 \mathrm{~nm}$ dengan nilai absorbansi 0,5. FTIR menunjukkan pengurangan dan pergeseran serapan pada gugus fungsi hidroksil $(-\mathrm{OH})$ pada bilangan gelombang $3323 \mathrm{~cm}^{-1}$ dan hadirnya puncak serapan pada $560 \mathrm{~cm}^{-1}$. XRD menunjukkan puncak kristalinitas yang spesifik nanopartikel perak pada sudut 20: $33,24^{\circ} ; 39,98^{\circ} ; 61,23^{\circ}$; dan $79,13^{\circ}$ dengan struktur kristal kubus berpusat muka (FCC) dengan ukuran kristalit sebesar $15 \mathrm{~nm}$. Analisis PSA memperlihatkan distribusi ukuran partikel perak sebesar 43,5 nm dan nilai PDI 0,4. Analisis TEM menunjukkan ukuran nanopartikel perak sebesar $20 \mathrm{~nm}$ dengan bentuk partikel bulat.
\end{abstract}

Kata kunci: Bioreduksi, Nanopartikel Perak, Tandan Kosong Kelapa Sawit 


\section{INTRODUCTION}

Nano-sized material is new, unique, and superior physical and chemical properties compared to its bulk structure due to the increase of the ratio of surface area per volume of the material or particle [1]. In the latest decade, metal nanoparticles are the most widely studied because it is easy to synthesize. Moreover, these materials have a wide range of applications such as catalysts, detectors, surface, coating agents, and antibacterial. Metallic nanoparticles which mostly studied are silver $(\mathrm{Ag})$ [2-3], gold $(\mathrm{Au})$ [4], platinum $(\mathrm{Pt})$ [5], and palladium (Pd) [6]. Colloids of silver nanoparticles were successfully synthesized using silver nitrate precursors with $\mathrm{pH}$ and temperature variations. The success of reducing $\mathrm{Ag}^{+}$to $\mathrm{Ag}^{0}$ ions is marked by a brown discoloration [3].

$\mathrm{Ag}$ nanoparticle is an interesting material to be studied because it has a variety of particle sizes and good particle stability so that it can be applied in the industry [7]. Applications of silver nanoparticles are widely used as efficiency enhancement of dye-sensitized solar cells [8], photothermal treatment of ovarian cancer [9], antibacterial activity [10], biological activities [11], and antibacterial additive [12]. Ag nanoparticles can be synthesized with several methods, including chemical reduction. This method is often used due to its more comfortable and economical [13]. The synthesis of silver nanoparticles requires a reducing and capping agent. The capping agent used to stabilize a particle size of silver to prevent agglomeration [14]. The edible polymer is typical material widely used as a capping agents [15].

Meanwhile, there are many reducing agents which used to reduce $\mathrm{Ag}^{+}$to $\mathrm{Ag}^{0}$ ions on silver nitrate and silver chloride precursors such as $\mathrm{NaOH}$ [16], ammonia [17], sodium citrate and $\mathrm{NaCl}$ [18], and polyvinyl alcohol [19]. However, it is hazardous and not environmentally friendly. Therefore, we would like to replace hazardous materials that have been used in previous studies by using natural ingredients. Currently, this method is called a green synthesis method to produce metallic nanoparticles. The use of eco-friendly reducing agents such as leaf, flower, seed, and root extracts in plants is one of the methods on the synthesis of silver nanoparticles.

Natural reducing used on the synthesis of silver nanoparticles such as, Terminalia arjuna bark extract [20], Triticum aestivum [21], aqueous extract of $P$. peruviana [22], herbal plant of Solanum trilobatum [23], Euphorbia amygdaloides [10], Citrullus lanatus fruit rind extract [24], Honey [25], Annona muricata [26], Fenugreek seed extract [27], Murraya koeniigi L [28], Orange peel extract [29], Sugar [30], Trigonella foenumgraecum [31], Impatiens balsamina and Lantana camara [7], Pelargonium sidoides DC [32], Aspergillus fumigatus [33], Moringa oleifera oil [34], Rumex hymenosepalus [35], Crinum latifolium [36]
Chlorophytum borivilianum L [37], and Ligustrum lucidum leaves [38], successfully used as a medium in the formation of silver nanoparticles.

Based on the facts mentioned above, in this research, the green synthesis of $\mathrm{Ag}$ nanoparticles was carried out using OPEFB because of abundant resources in Indonesia especially in the sanggau area (West Kalimantan). Oil palm plants produce $23 \mathrm{wt} \%$ of OPEFB. OPEFB containing $45 \mathrm{wt} \%$ of cellulose and $16.5 \mathrm{wt} \%$ of lignin. Phenolic compounds can be produced from lignin extraction in the OPEFB [39].

Recently, the synthesis of silver nanoparticles with a green chemistry approach has been successfully carried out. The use of eco-friendly reducing agents such as leaf, flower, seed, and root extracts in plants is one of the methods on the synthesis of silver nanoparticles. In this research, silver nanoparticles will be synthesized using oil palm empty fruit bunch (OPEFB) extract. Hydroxyl groups $(-\mathrm{OH})$ in phenol on OPEFB predicted can be used as a source of electrons in reducing $\mathrm{Ag}^{+}$to $\mathrm{Ag}^{0}$ ions. In this study, oil palm empty fruit bunch (OPEFB)'s waste extracted using methanol, n-hexane, ethyl-acetate, and water. The water fraction results of oil palm empty fruit bunch extraction served as a medium for synthesizing of silver nanoparticles. The bioreduction reaction of $\mathrm{Ag}^{+}$to $\mathrm{Ag}^{0}$ took place at room temperature.

\section{EXPERIMENTAL METHOD}

\section{Materials and Instruments}

Oil palm empty fruit bunch (Elaeis guineensis $J$ ) (OPEFB) was collected from Sanggau area, (West Kalimantan, Indonesia). Silver nitrate $(99,98 \%)$ was purchased from Merck (Darmstad, Germany). Methanol (95\%), n-hexane (99\%), ethyl-acetate $(99 \%)$ purchased from Sigma-Aldrich (Missouri, United States).

The colloid of silver nanoparticles was characterized using UV-Vis Spectrophotometer (Shimadzu 2600) at 200-800 nm wavelength, FTIR Spectroscopy (Shimadzu Prestige 21) at 4000-400 $\mathrm{cm}^{-1}$ wavenumber, X-ray diffraction (XRD Shimadzu 610) at diffraction angles $(2 \theta) 20^{\circ}-80^{\circ}$, Particle Size Analyzer (PSA Malvern ZEN 1600) with dynamic light scattering system, Transmission Electron Microscopy (TEM JEM 1400) using $350 \mathrm{keV}$ of electron beam energy.

\section{Method and Procedure}

To obtain phenolic compounds in the OPEFB extract, a maceration process was carried out. Amount of $100 \mathrm{~g}$ of OPEFB was macerated with $200 \mathrm{~mL}$ methanol for 7 days at room temperature. Then, the extract of OPEFB methanol fraction was partitioned using nhexane, ethyl-acetate, and distilled water to obtain a sample of OPEFB extract [40]. 
Synthesis of silver nanoparticles was conducted by adding $1 \mathrm{~mL}$ of OPEFB extract to $10 \mathrm{~mL}$ of silver nitrate solution $\left(1 \times 10^{-4} \mathrm{M}\right)$. As a comparison, the absorption peak was measured on solution precursor pure of silver nitrate $\left(1 \times 10^{-4} \mathrm{M}\right)$ and OPEFB extract of water fraction. The reaction of bioreduction $\mathrm{Ag}^{+}$to $\mathrm{Ag}^{0}$ was carried out at room temperature for 1 hour. Discoloration from clear to brown indicated that colloid of silver nanoparticles had been formed [38].

\section{RESULT AND DISCUSSION}

Silver nanoparticles were successfully synthesized using natural bioreductor from the extract of OPEFB. The results of the extraction of oil palm empty fruit bunch (OPEFB) is $5 \mathrm{wt} \%$ of the extracted concentration of a stock solution. Figure 1 shows the bioreduction reaction of silver nanoparticles using the extract of oil palm empty fruit bunch (OPEFB). Visually, the formation of colloid of silver nanoparticles can be observed by the discoloration of the solution from clear to brown [38]. The mechanism is equation (1):
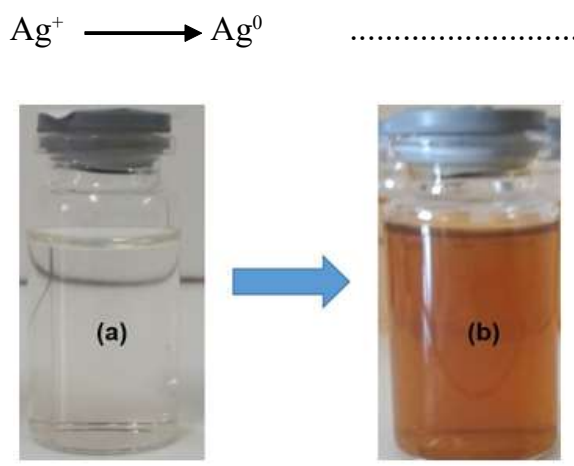

Figure 1. (a) Before and (b) After Bioreduction

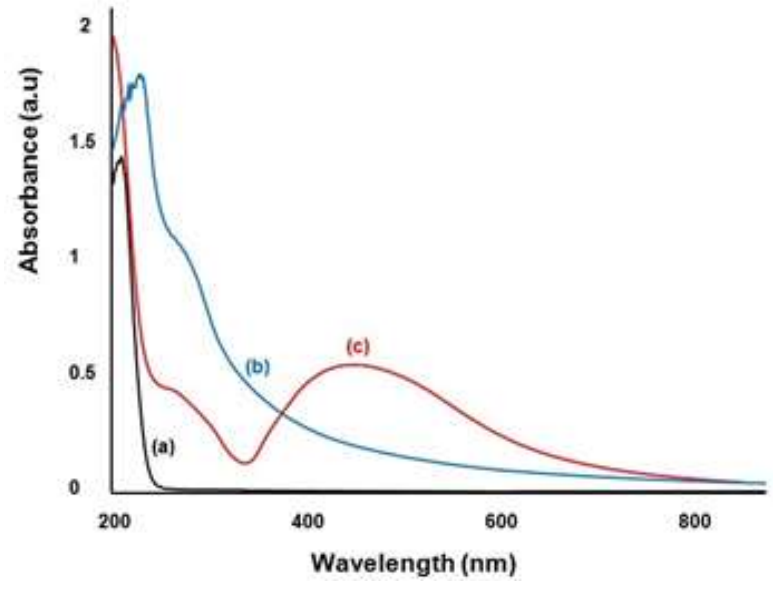

Figure 2. UV-Vis Spectra (a) $\mathrm{AgNO}_{3}$ precursor, (b) Oil palm empty fruit bunch (OPEFB), and (c) Colloid of silver nanoparticles.

Table 1. Changes of the absorption peak between OPEFB extract and colloid of silver nanoparticles.

\begin{tabular}{ccc}
\hline $\begin{array}{c}\text { Functional } \\
\text { Groups }\end{array}$ & OPEFB $\left(\mathrm{cm}^{-1}\right)$ & Silver Nanoparticles $\left(\mathrm{cm}^{-1}\right)$ \\
\hline$-\mathrm{OH}$ & 3323 & 3375 \\
$\mathrm{C}=\mathrm{O}$ & 1760 & 1620 \\
$\mathrm{C}=\mathrm{C}$ & 1650 & 1388 \\
$\mathrm{C}-\mathrm{H}$ & 1350 & 1080 \\
\hline
\end{tabular}

Figure 3 shows the FTIR spectrum of silver nanoparticles and OPEFB extract. Figure $3 \mathrm{c}$ shows the decrease of absorption peak in the hydroxyl group ($\mathrm{OH})$ at wavenumbers of $3323 \mathrm{~cm}^{-1}$. This result indicated that the bioreduction of $\mathrm{Ag}^{+}$to $\mathrm{Ag}^{0}$ has been successful. The formation of silver nanoparticles is characterized by the presence of absorption peaks at wavenumbers of $560 \mathrm{~cm}^{-1}[23]$.

Functional groups of hydroxyl (-OH) in these phenol compounds are predicted as ions sources of reducing $\mathrm{Ag}^{+}$to $\mathrm{Ag}^{0}$ [41].

The colloid of silver nanoparticles has a maximum absorption peak $\left(\lambda_{\max }\right)$ at a wavelength of $420 \mathrm{~nm}$ with an absorbance value of 0.5, as shown in Figure 2(c). Figure 2 shows the surface plasmon resonance (SPR) phenomena of silver nanoparticles characterized using a UV-Vis spectrophotometer.

Phenomena of surface plasmon resonance (SPR) is only owned by the colloid of metal [2]. Both $\mathrm{AgNO}_{3}$ precursor and OPEFB which showed on Figures 2(a) and 2(b) respectively have not a maximum absorption peak.

Based on the spectrum of FTIR spectroscopy, OPEFB extract has four absorption peaks at wavenumbers: $3323 \mathrm{~cm}^{-1}$ (\%OH stretching); $1760 \mathrm{~cm}^{-1}$ $\left(\mathrm{C}=\mathrm{O}\right.$ ketone); $1650 \mathrm{~cm}^{-1}(\mathrm{C}=\mathrm{C}$ alkene $)$; and $1350 \mathrm{~cm}^{-1}$ (C\%H alkane) [42].

Differences of functional groups at OPEFB extract and colloid of silver nanoparticles are seen in Table 1.

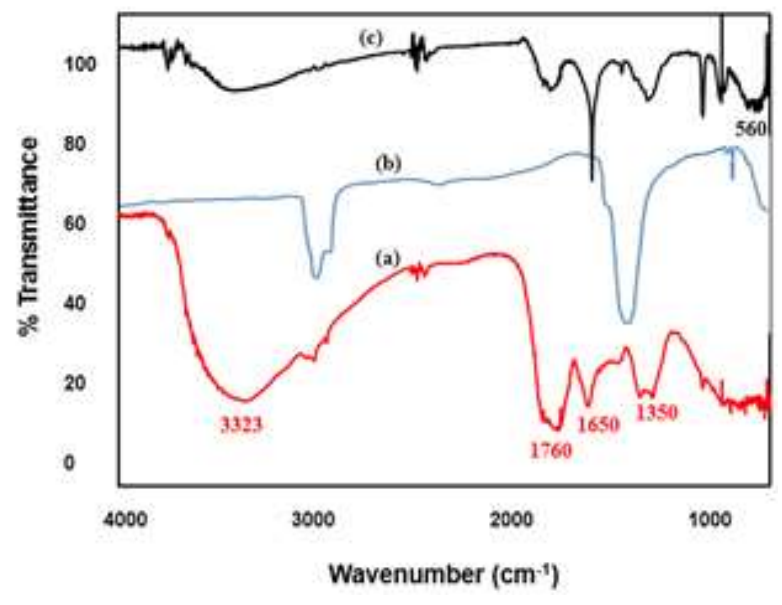

Figure 3. FTIR Spectrum (a) Oil palm empty fruit bunch (OPEFB), (b) $\mathrm{AgNO}_{3}$, and (c) Colloid of silver nanoparticles

Figure 4 shows the crystallinity of silver nanoparticles. Silver nanoparticles have a four specific peaks at $2 \theta: 33.24^{\circ} ; 39.98^{\circ} ; 61.23^{\circ}$; and $79.13^{\circ}$ which 


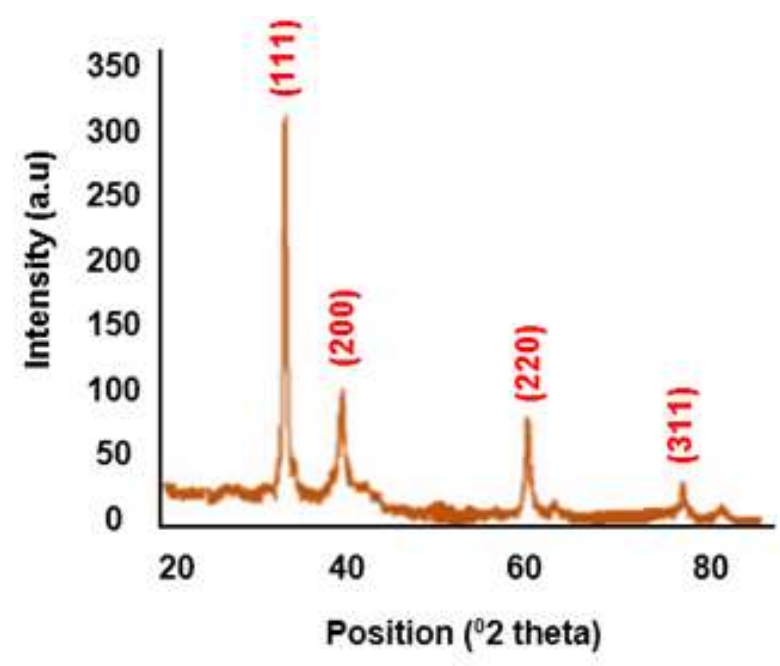

Figure 4. XRD pattern of silver nanoparticles

revealed Bragg's reflection from $\mathrm{Ag}(111), \mathrm{Ag}$ (200), $\mathrm{Ag}$ (220), and $\mathrm{Ag}(311)$.

Silver nanoparticles have a face-centered cubic crystal structure (FCC) with a crystallite size of $15 \mathrm{~nm}$. The crystal structure of silver nanoparticles has been published according to JCPDS data (No.04-0783) [43]

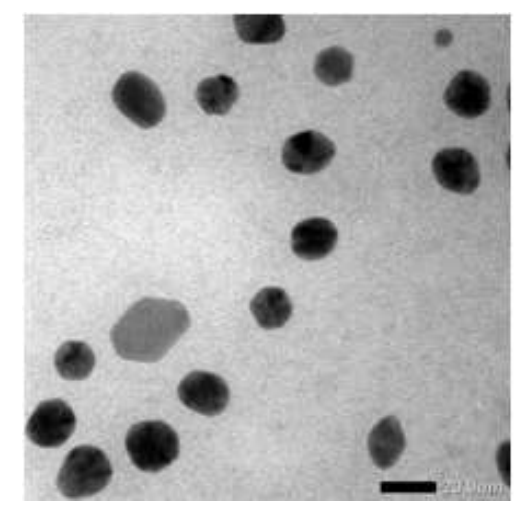

Figure 5. TEM images of silver nanoparticles synthesized by oil palm empty fruit bunch (OPEFB) extract.

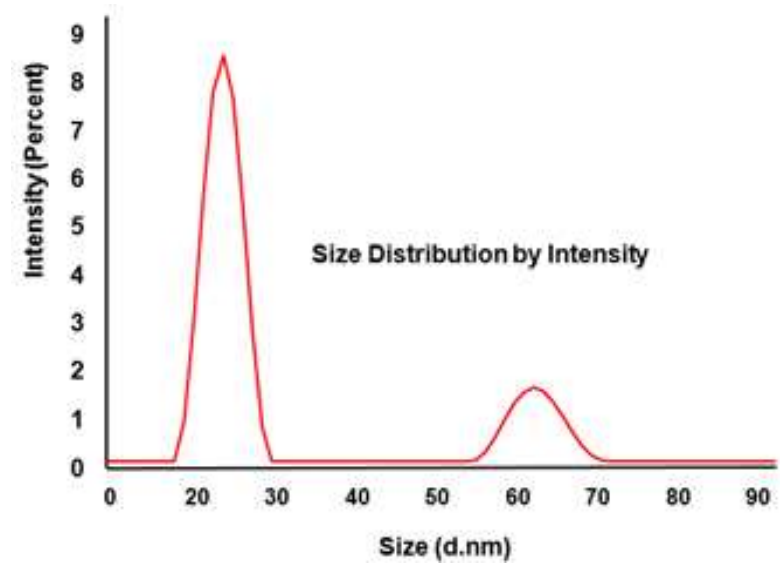

Figure 6. PSA distribution of silver nanoparticles synthesized by oil palm empty fruit bunch (OPEFB) extract.
TEM data shows that silver nanoparticles have a sphere shape with an average particle size of $20 \mathrm{~nm}$ [44]. Figure 5 shows the size distribution and shape of the silver nanoparticles.

Based on the data of particle size analyzer which showed in figure 6 . Silver nanoparticles have a particle size distribution of $43.5 \mathrm{~nm}$ and a polydispersity index (PDI) value of 0.4 [45].

\section{CONCLUSION}

Silver nanoparticles were successfully synthesized using an extract of oil palm empty fruit bunch (OPEFB). The functional of secondary metabolite compounds in OPEFB extract as a source of electrons in reduction $\mathrm{Ag}^{+}$to $\mathrm{Ag}^{0}$ ions and a capping agent in the synthesis of silver nanoparticles. The results of UV-Vis showed the maximum absorption peak of silver nanoparticles at a wavelength of $420 \mathrm{~nm}$ with an absorbance value of 0.5. Data of FTIR showed a reduction in absorption peaks at wavenumbers $3323 \mathrm{~cm}^{-1}(-\mathrm{OH})$ and the presence of absorption peaks at $560 \mathrm{~cm}^{-1}$ indicating silver nanoparticles were successfully formed. XRD showed an average crystal size of silver nanoparticles of $15 \mathrm{~nm}$ with a face-centered cubic crystal shape. Results of PSA showed that the size distribution of silver nanoparticles is $43.5 \mathrm{~nm}$. In contrast, TEM observation showed that shape of silver nanoparticles was a sphericale with an average particle size of $20 \mathrm{~nm}$.

\section{ACKNOWLEDGEMENTS}

Thanks to the ministry of research and technology through the novice lecturer competitive research grant(PDP) 2020 with contract No: 10/E1/KPT/ 2020 and higher education service Institutions (LLDIKTI III) Jakarta with contract No: 005/LL3/PG/2020.

\section{REFERENCES}

[1]. Beyene, H. Dargo, A. A. Werkneh, H. K. Bezabh, T. G. Ambaye. "Synthesis paradigm and applications of silver nanoparticles (AgNPs), a review." Sustainable Materials and Technologies, 08 (01), 2017.

[2]. Agustina, Munawarah, S. A. Lumi, S. Nur. "Green Synthesis Nanopartikel Perak (AgNps) Terkonjugasi Etil Parametoksi Sinamat (Epms) Sebagai Bahan Tabir Surya." Jurnal Farmasi Galenika (Galenika Journal of Pharmacy) (eJournal), 4 (2): 98-105, 2018.

[3]. Hasri, I. Dini, S. P. J. Negara, Subaer. "Biosynthesis of Silver Nnaoparticles Made from Green Tea Leaf Extract (Camellia sinensis)." Materials Science Forum, 967 (161), 2019.

[4]. Wang, J. X. Wu, C. Wang, Z. Rong, H. Ding, H. Li, S. Li, N. Shao, P. Dong, R. Xiao, S. Wang. "Facile 
synthesis of Au-coated magnetic nanoparticles and their application in bacteria detection via a SERS method." ACS Appl. Mater. Interfaces, 10 (1021), 2016.

[5]. Dasdelen, Z. Y. Yildiz, S. Eris, F. Sen. "Enhanced electrocatalytic activity and durability of $\mathrm{Pt}$ nanoparticles decorated on GO-PVP hybride material for methanol oxidation reaction." Applied Catalysis B: Environmental, 8 (11), 2017.

[6]. Y. Yin, N. Ma, J. Xue, G. Wang, S. Liu, H. Li, P. Guo. "Insight into the role of Poly(vinylpyrrolidone) in the synthesis of Palladium nanoparticles and their electrocatalytic properties." Langmuir, (10), 2019.

[7]. Aritonang, Henry F., Harry Koleangan, and Audy D. Wuntu. "Synthesis of Silver Nano particles Using Aqueous Extract of Medicinal Plants' (Impatiens Balsamina and Lantana Camara) Fresh Leaves and Analysis of Antimicrobial Activity." International Journal of Microbiology, 2019.

[8]. S. Saravanan, R. Kato, M. Balamurungan, S. Kaushik, T. Soga. "Efficiency improvement in dye sensitized solar cells by the plasmonic effect of green synthesized silver nanoparticles." Journal of Science: Advanced Materials and Devices, (10), 2017.

[9]. Liu, Bing, J. Zhou, B. Zhang, J. Qu. "Synthesis of $\mathrm{Ag} @ \mathrm{Fe}_{3} \mathrm{O}_{4}$ Nanoparticles for Photothermal Treatment of Ovarian Cancer." Journal of Nanomaterials, 2019.

[10]. Cicek, Semra, A. A. Gungor, A. Adiguzel, H. Nadaroglu. "Biochemical Evaluation and Green Synthesis of Nano Silver Using Peroxidase from Euphorbia (Euphorbia Amygdaloides) and Its Antibacterial Activity." Journal of Chemistry, 2015.

[11]. Khan, F. Ali, M. Zahoor, A. Jalal, A. U. Rahman. "Green Synthesis of Silver Nanoparticles by Using Ziziphus Nummularia Leaves Aqueous Extract and Their Biological Activities." Journal of Nanomaterials, 2016. https://doi.org/10.1155/2016/ 8026843.

[12]. W. Mendoza, A. Miguel, L. M. Jothar, S. O. Ruiz, E. G. V. Leal, L. M. C. Covarrubias, Z. V. Q. Jurado, E. Ortega, E. Pérez. "Antibacterial Additive for Polystyrene Based on Silver Nanoparticles Supported on Titanium Dioxide." International Journal of Polymer Science, 2016. https://doi.org/ 10.1155/2016/1641352.

[13]. Yaqoob, A. Ali, K. Umar, M. Nasir, M. Ibrahim. "Silver nanoparticles: various methods of synthesis, size affecting factors and their potential applications - a review." Applied Nanoscience, 2020. https://doi.org/10.1007/s13204-020-01318.

[14]. Mirzaei, Ali, K. Janghorban, B. Hashemi, M. Bonyani, S. G. Leonardi, G. Neri. "Characterization and optical studies of PVP-capped silver nanoparticles." Journal of Nanostructure in Chemistry, 2017. DOI 10.1007/s40097-016-0212-3.

[15]. Froiio, Francesca, A. Mosaddik, M. T. Morshed, D. Paolino, H. Fessi, A. Elaissari. "Edible Polymers for Essential Oils Encapsulation: Application in Food Preservation." Industrial \& Engineering Chemistry Research, 2019. doi:10.1021/ acs.iecr.9b02418.

[16]. Rather, R. Ahmad, K. Ramandeep, Sarwana, N. Das, B. Pal. "Impact of reducing and capping agents on carbohydrates for the growth of $\mathrm{Ag}$ and $\mathrm{Cu}$ nanostructures and their antibacterial activities." Particuology, 2019. https://doi.org/10.1016/ j.partic.2018.01.00.

[17]. Meader, V. Kathryn, M. G. John, L. M. F. Batista, S. Ahsan, K. M. Tibbetts. "Radical Chemistry in a Femtosecond Laser Plasma: Photochemical Reduction of $\mathrm{Ag}^{+}$in Liquid Ammonia Solution." Molecules, 2018. https://doi.org/10.3390/ molecules2303053.

[18]. Petrucci, D. Oscar, R. J. Hilton, J. K. Farrer, R. K. Watt. "A Ferritin Photochemical Synthesis of Monodispersed Silver Nanoparticles That Possess Antimicrobial Properties." Journal of Nanomaterials, 2019. https://doi.org/10.1155/2019/ 9535708.

[19]. Nguyen, D. Tan, K. L. Ly, N. M. P. Tran, M. H. Ho, T. T. P. Tran, T. H. Nguyen, D. N. T. Nhi, V. T. Vo. "Effect of Microwave Irradiation on Polyvinyl Alcohol as a Carrier of Silver Nanoparticles in Short Exposure Time." International Journal of Polymer Science, 2019. https://doi.org/10.1155/2019/ 3623907.

[20]. Ahmed, Qadruddin, N. Gupta, A. Kumar, S. Nimesh. "Antibacterial efficacy of silver nanoparticles synthesized employing Terminalia arjuna bark extract." Artificial Cells, Nanomedicine, and Biotechnology, 2016. doi:10.1080/ 21691401.2016.1215328.

[21]. Ahdelsalam, R. Nader, A. A. Megeed, H. M. Ali, M. Z. M. Salem, Muwafaq, F. A. Al-Hayali, M. S. Elshikh. "Genotoxicity effects of silver nanoparticles on wheat (Triticum aestivum L.) root tip cells." Ecotoxicology and Environmental Safety, 2018. https://doi.org/10.1016/ j.ecoenv.2018.02.06.

[22]. Timoteo, C. de Oliveira, R. Paiva, M. V. dos Reis, P. I. C. Claro, L. M. Ferraz, J. M. Marconcini, J. E. de Oliviera. "In vitro growth of Physalis peruviana L. affected by silver nanoparticles." 3 Biotech, 2019. doi:10.1007/s13205-019-1674-z.

[23]. Ramanathan, Santheraleka, S. C. B. Gopinath, P. Anbu, T. Lakshmipriya, F. H. Kasim, C. G. Lee. "Eco-friendly synthesis of Solanum trilobatum extract-capped silver nanoparticles is compatible with good antimicrobial activities." Journal of 
Molecular Structure, 2018. https://doi.org/10.1016/ j.molstruc.2018.01.056.

[24]. Ndikau, Michael, N. M. Noah, D. M. Andala, E. Masika. "Green Synthesis and Characterization of Silver Nanoparticles Using Citrullus Lanatus Fruit Rind Extract." International Journal of Analytical Chemistry, 2017. https://doi.org/10.1155/2017/ 8108504

[25]. Balasooriya, E. Roshan, C. D. Jayasinghe, U. A. Jayawardena, R. Weerakkodige, D. Ruwanthika, R. M. D. Silva, P. V. Udagama. "Honey Mediated Green Synthesis of Nanoparticles: New Era of Safe Nanotechnology." Journal of Nanomaterials, 2017. https://doi.org/10.1155/2017/591983.

[26]. S. Navarro, M. del Carmen, C. A. R. Torres, N. N. Mart'ýnez, R. S'anchez, G. M. Castañon, I. D. Montero, F. Ruiz. "Cytotoxic and Bactericidal Effect of Silver Nanoparticles Obtained by Green Synthesis Method Using Annona Muricata Aqueous Extract and Functionalized with 5Fluorouracil." Bioinorganic Chemistry and Applications, 2018. https://doi.org/10.1155/2018/ 6506381.

[27]. Deshmukh, R. Aarti, A. Gupta, B. S. Kim. "Ultrasound Assisted Green Synthesis of Silver and Iron Oxide Nanoparticles Using Fenugreek Seed Extract and Their Enhanced Antibacterial and Antioxidant Activities." BioMed Research International, 2019. https://doi.org/10.1155/2019/ 1714358 .

[28]. Qais, F. Abul, A. Shafiq, H. M. Khan, Fohad. M. Husain, A. R. Khan, B. Alenazi, A. Alsalme, I. Ahmad. "Antibacterial Effect of Silver Nanoparticles Synthesized Using Murraya Koenigii (L.) against Multidrug-Resistant Pathogens." Bioinorganic Chemistry and Applications, 2019. https://doi.org/10.1155/2019/ 4649506.

[29]. Skiba, I. Margarita, V. I. Vorobyova. "Synthesis of Silver Nanoparticles Using Orange Peel Extract Prepared by Plasmochemical Extraction Method and Degradation of Methylene Blue under Solar Irradiation." Advances in Materials Science and Engineering, 2019. https://doi.org/10.1155/2019/ 8306015.

[30]. Hemmati, Shohreh, E. R. Roberts, C. Scott, M. T. Harris. "Artificial Sweeteners and Sugar Ingre dients as Reducing Agent for Green Synthesis of Silver Nanoparticles." Journal of Nanomaterials, 22-26, 2019. https://doi.org/ 10.1155/2019/9641860.

[31]. Awad, A. Manal, A. A. Hendi, K. M. O. Ortashi, A. B. Alanazi, B. A. ALZahrani, D. A. Soliman. "Greener Synthesis, Characterization, and Antimicro biological Effects of Helba Silver NanoparticlePMMA Nanocomposite." International Journal of Polymer Science, 2019. https://doi.org/10.1155/ 2019/437950.

[32]. Kgatshe, Mogomotsi, O. S. Aremu, L. K. Seru, R. Gopane. "Characterization and Antibacterial Activity of Biosynthesized Silver Nanoparticles Using the Ethanolic Extract of Pelargonium Sidoides DC.” Journal of Nanomaterials, 2019. https://doi.org/10.1155/2019/3501234.

[33]. Shahzad, Asma, H. Saeed, M. Iqtedar, S. Z. Hussain, A. Kaleem, R. Abdullah, S. Sharif. "Size-Controlled Production of Silver Nanoparticles by Aspergillus Fumigatus BTCB10: Likely Antibacterial and Cytotoxic Effects." Journal of Nanomaterials, 2019. https://doi.org/10.1155/2019/5168698.

[34]. Amina, Musarat, N. M. Al Musayeib, N. A. Alarfaj, M. F. El-Tohamy, H. E. Orabi, S. I. Bukhari, A. Z. Mahmoud. "Exploiting the Potential of Moringa Oleifera Oil/Polyvinyl Chloride Polymeric Bionanocomposite Film Enriched with Silver Nanoparticles for Antimicrobial Activity." International Journal of Polymer Science, 2019. https://doi.org/10.1155/2019/5678149.

[35]. A. Cirerol, F. Javier, M. A. L. Torres, E. R. León, C. R. Beas, A. M. Higuera, H. H. Lara, S. Vergara. "Silver Nanoparticles Synthesized with Rumex Hymenosepalus: A Strategy to Combat Early Mortality Syndrome (EMS) in a Cultivated White Shrimp." Journal of Nanomaterials, 2019. https:// doi.org/10.1155/2019/8214675.

[36]. Vo, T. Truc, T. T. N. Nguyen, T. T. T. Huynh, T. T. T. Vo, T. T. N. Nguyen, D. T. Nguyen, V. S. Dang, C. H. Dang, T. D. Nguyen. "Biosynthesis of Silver and Gold Nanoparticles Using Aqueous Extract from Crinum Latifolium Leaf and Their Applications Forward Antibacterial Effect and Wastewater Treatment." Journal of Nanomaterials, 2019. https://doi.org/10.1155/2019/8385935.

[37]. Huang, Fengchang, Y. Long, Q. Liang, B. Purushotham, M. K. Swamy, Y. Duan. "Safed Musli (Chlorophytum Borivilianum L.) Callus-Mediated Biosynthesis of Silver Nanoparticles and Evaluation of Their Antimicrobial Activity and Cytotoxicity against Human Colon Cancer Cells." Journal of Nanomaterials, 2019. https://doi.org/ 10.1155/2019/2418785.

[38]. Huang, Weidong, M. Yan, H. Duan, Y. Bi, X. Cheng, H. Yu. "Synergistic Antifungal Activity of Green Synthesized Silver Nanoparticles and Epoxiconazole against Setosphaeria Turcica." Journal of Nanomaterials, 2020. https://doi.org/ $10.1155 / 2020 / 9535432$.

[39]. Nurhadini, Nurhadini, I. M. Arcana. "Synthesis of Cellulose Acetate From Oil Palm Empty Fruit Bunch and Its Properties As Polymer Electrolyte Membranes on Lithium Ion Battery." Jurnal Kimia Mulawarman, 15 (2), 111, 2018. https://doi.org/ $10.30872 / \mathrm{jkm} . \mathrm{v} 15 \mathrm{i} 2.612$. 
[40]. Siti, W dan Uswatun, H. "Ekstraksi Zat Warna dari Kluwek (Pangium edule Reinw) Menggunakan Berbagai Pelarut." Ekologia, 18 (1), 40-48, 2018.

[41]. Amran, U. Adli, S. Zakaria, C. H. Chia, Z. Fang, M. Z. Masli. "Production of Liquefied Oil Palm Empty Fruit Bunch Based Polyols via Microwave Heating.” Energy Fuels, 2017. https://doi.org/ 10.1021/acs.energyfuels.7b02098.

[42]. Pradana, M. Aditya, H. Ardhyananta, M. Farid. "Pemisahan Selulosa Dari Lignin Serat Tandan Kosong Kelapa Sawit Dengan Proses Alkalisasi Untuk Penguat Bahan Komposit Penyerap Suara." Jurnal Teknik ITS, 6 (2), 413-16, 2017. https:// doi.org/10.12962/j23373539.v6i2.24559.

[43]. M. Parthibavarman, S. Bhuvaneshwari, M. Jayashree, R. Boopathiraja. "Green Synthesis of
Silver (Ag) Nanoparticles Using Extract oof Apple and Grape and with Enhanced Visible Light Photocatalytic Activity." BioNanoScience, 2019.

[44]. V. T. Nguyen, "Sunlight-Driven Synthesis of Silver Nanoparticles using Pomelo Peel Extract and Antibacterial Testing." Journal of Chemistry, Article ID 6407081, 1-9, 2020. https://doi.org/ $10.1155 / 2020 / 6407081$.

[45]. O. D. Petrucci, R. J. Hilton, J. K. Farrer, R. K. Watt. "A Ferritin Photochemical Synthesis of Monodispersed Silver Nanoparticles That Possess Antimicrobial Properties." Journal of Nanomaterials, Article ID 9535708, 1-8, 2019. https://doi.org/10.1155/2019/9535708. 